\title{
Joining the club: First detection of African swine fever in wild boar in Germany
}

\author{
Carola Sauter-Louis ${ }^{1}$, Jan Forth ${ }^{1}$, C. Probst ${ }^{1}$, Christoph Staubach $^{1}$, Andreas Hlinak ${ }^{2}$, \\ Annett Rudovsky ${ }^{3}$, Diana Holland ${ }^{3}$, Patricia Schlieben ${ }^{2}$, Melanie Göldner ${ }^{2}$, Juliane \\ Schatz $^{2}$, Sabine Bock ${ }^{2}$, Melina Fischer ${ }^{1}$, Katja Schulz ${ }^{1}$, Timo Homeier-Bachmann ${ }^{1}$, Ralf \\ Plagemann $^{4}$, Ulf Klaaß ${ }^{3}$, Ronny Marquart ${ }^{3}$, Thomas Mettenleiter ${ }^{1}$, Martin Beer ${ }^{1}$, Franz \\ Conraths $^{1}$, and Sandra Blome ${ }^{1}$ \\ ${ }^{1}$ Friedrich-Loeffler-Institut Bundesforschungsinstitut fur Tiergesundheit \\ ${ }^{2}$ Landeslabor Berlin Brandenburg \\ ${ }^{3}$ Landesamt für Arbeitsschutz Verbraucherschutz und Gesundheit \\ ${ }^{4}$ Ministerium für Soziales, Gesundheit, Integration und Verbraucherschutz des Landes \\ Brandenburg
}

October 12, 2020

\begin{abstract}
African swine fever (ASF) has spread across many countries in Europe since the introduction into Georgia in 2007. We report here on the first cases of ASF in wild boar detected in Germany close to the border with Poland. In addition to the constant risk of ASF virus (ASFV) spread through human activities, movements of infected wild boar also represent a route of introduction. Since ASF emerged in Western Poland in November 2019, surveillance efforts, in particular examination of wild boar found dead, were intensified in the regions of Germany bordering with Poland. The first case of ASF in wild boar in Germany was therefore detected by passive surveillance and confirmed on 10th September 2020. By 24th September 2020,32 cases were recorded. Testing of samples from tissues of carcasses in different stages of decomposition yielded cycle threshold values from 18 to 36 in the OIE-recommended PCR which were comparable between the regional and national reference laboratory. Blood swabs yielded reliable results, indicating that the method is suitable also under outbreak conditions. Phylogenetic analysis of the ASFV whole-genome sequence generated from material of the first carcass detected in Germany, revealed that it groups with ASFV genotype II including all sequences from Eastern Europe, Asia and Belgium. However, some genetic markers including a $14 \mathrm{bp}$ tandem repeat duplication in the $\mathrm{O} 174 \mathrm{~L}$ gene were confirmed that have so far been detected only in sequences from Poland (including Western Poland). Epidemiological investigations that include estimated postmortem intervals of wild boar carcasses of infected animals suggest that ASFV had been introduced into Germany in the first half of July 2020 or even earlier.
\end{abstract}

\section{Rapid communication}

Joining the club: First detection of African swine fever in wild boar in Germany

Running title: African swine fever in Germany

Carola Sauter-Louis ${ }^{1+}$, Jan Hendrik Forth ${ }^{1+}$, Carolina Probst ${ }^{1}$, Christoph Staubach ${ }^{1}$, Andreas Hlinak ${ }^{2}$, Annett Rudovsky ${ }^{3}$, Diana Holland ${ }^{3}$, Patricia Schlieben ${ }^{2}$, Melanie Göldner ${ }^{2}$, Juliane Schatz ${ }^{2}$, Sabine Bock ${ }^{2}$, Melina Fischer ${ }^{1}$, Katja Schulz ${ }^{1}$, Timo Homeier-Bachmann ${ }^{1}$, Ralf Plagemann ${ }^{4}$, Ulf Klaaß ${ }^{3}$, Ronny Marquart ${ }^{3}$, Thomas C. Mettenleiter ${ }^{1}$, Martin Beer ${ }^{1}$, Franz J. Conraths ${ }^{1}$, Sandra Blome ${ }^{1}$

+ these authors contributed equally 
${ }^{1}$ Friedrich-Loeffler-Institut, Südufer 10, 17493 Greifswald - Insel Riems, Germany

${ }^{2}$ Landeslabor Berlin-Brandenburg, Gerhard-Neumann-Str. 2, 15236 Frankfurt (Oder)

${ }^{3}$ Landesamt für Arbeitsschutz, Verbraucherschutz und Gesundheit, Abteilung Verbraucherschutz, Dezernat V2, Dorfstr. 1, 14513 Teltow OT Ruhlsdorf

4 Ministerium für Soziales, Gesundheit, Integration und Verbraucherschutz des Landes Brandenburg, Henning-von-Tresckow-Straße 2-13, 14467 Potsdam

*Corresponding Author:

PD Dr. Carola Sauter-Louis

Friedrich-Loeffler-Institut

Südufer 10

17493 Greifswald - Insel Riems

Phone: +49-38351-7-1893 / Email:carola.sauter-louis@fli.de

\section{Summary}

African swine fever (ASF) has spread across many countries in Europe since the introduction into Georgia in 2007. We report here on the first cases of ASF in wild boar detected in Germany close to the border with Poland. In addition to the constant risk of ASF virus (ASFV) spread through human activities, movements of infected wild boar also represent a route of introduction. Since ASF emerged in Western Poland in November 2019, surveillance efforts, in particular examination of wild boar found dead, were intensified in the regions of Germany bordering with Poland. The first case of ASF in wild boar in Germany was therefore detected by passive surveillance and confirmed on 10th September 2020. By 24th September 2020, 32 cases were recorded. Testing of samples from tissues of carcasses in different stages of decomposition yielded cycle threshold values from 18 to 36 in the OIE-recommended PCR which were comparable between the regional and national reference laboratory. Blood swabs yielded reliable results, indicating that the method is suitable also under outbreak conditions. Phylogenetic analysis of the ASFV whole-genome sequence generated from material of the first carcass detected in Germany, revealed that it groups with ASFV genotype II including all sequences from Eastern Europe, Asia and Belgium. However, some genetic markers including a 14 bp tandem repeat duplication in the $\mathrm{O} 174 \mathrm{~L}$ gene were confirmed that have so far been detected only in sequences from Poland (including Western Poland). Epidemiological investigations that include estimated postmortem intervals of wild boar carcasses of infected animals suggest that ASFV had been introduced into Germany in the first half of July 2020 or even earlier.

Keywords: African swine fever, Germany, first case, epidemiology, virus sequence

\section{Introduction}

Over the past decade, African swine fever (ASF) has developed into a panzootic threat to domestic and wild boar worldwide (Blome, Franzke, \& Beer, 2020). Since 2014, ASF virus (ASFV) has been spreading in the European Union (Chenais et al., 2019). The virus was introduced into wild boar in Belgium in 2018 (Linden et al., 2019) and into the western part of Poland in 2019 (Mazur-Panasiuk, Walczak, Juszkiewicz, \& Wozniakowski, 2020) close to the respective German borders. While the situation in Belgium appears to be under control, the epidemic in Poland worsened. The first reported case of ASF in wild boar in Western Poland was found about $79 \mathrm{~km}$ from the German border. Between 1st November 2019 and 9th September 2020, a total of 1,037 cases in wild boar and eight outbreaks in domestic pigs were reported from this region (ADNS, as of 10th September 2020) which restriction zones in Poland extending to the German border. The nearest case of ASF in wild boar in Poland was located $10.4 \mathrm{~km}$ from the German border (confirmed on 26th March 2020). Here, we report on the first cases of ASF in wild boar in Germany, detected close to the German-Polish border in the Federal State of Brandenburg, including the results of epidemiological 
investigations, diagnostics and genetic characterization of the German ASFV isolate using whole-genome sequencing.

\section{Material and Methods}

\section{Epidemiological investigations}

Information on ASF cases in wild boar obtained by the local veterinary offices were entered into the German electronic animal disease information system (TSN, "Tierseuchennachrichtensystem", German National Animal Disease Database) (Kroschewski et al., 2006). These data sets contain the date of suspicion and disease confirmation, the location (geographical coordinates), where the animal had been hunted or found dead, as well as the age and gender of each individual wild boar.

In addition, for most carcasses, photographs and a "checklist for wild boar carcasses found in the field" (https://www.fli.de/fileadmin/FLI/IfE/AG_Forensik_Wildschwein/Erhebungsbogen_Wildschwein.pdf) were made available for epidemiological investigations or retrieved by epidemiologists of the Friedrich-Loeffler-Institut (FLI). These data were used to estimate the minimum postmortem interval (PMI) as previously described (Probst, Gethmann, Amendt, et al., 2020; Probst, Gethmann, Hohmann, et al., 2020). The minimum PMI, i.e. the latest possible time point of death, was estimated based on morphological characteristics of the carcass, i.e. the decomposition stage of different body parts and accumulated decomposition (fresh, bloated, active decay, advanced decay, dry, and remains), mean temperature (at $2 \mathrm{~m}$ height) and rainfall in the previous weeks (retrieved from the nearest weather station in Coschen, Brandenburg; German Weather Service, Offenbach, Germany), type of microhabitat (dry/moist, direct sunlight/shade, etc.), entomological activity, characteristics of the decomposition island and evidence for vertebrate scavenging. Euclidian distances between the cases in Germany and those in Western Poland were calculated in km using the software package sp (Pebesma \& Bivand, 2005) within the open source software $\mathrm{R}$ (http://www.r-project).

Data on ASF surveillance prior to the emergence of ASF in Germany were extracted from the CSF/ASF wild boar surveillance database of the European Union (https://surv-wildboar.eu) for the period from 1st November 2019 to 9th September 2020. This covered the whole period since cases of ASF had been reported from Western Poland. There was one individual data set for each wild boar, which contained the date and location, where the animal had been hunted or found dead. Furthermore, information was recorded on the circumstances of death for each animal, i.e. shot apparently healthy (active surveillance) or shot sick, found dead or involved in a traffic accident (passive surveillance).

\section{Laboratory diagnosis}

For qPCR at the regional laboratory (Landeslabor Berlin-Brandenburg, Frankfurt/Oder, Germany, LLBB), the commercial RealPCR ASFV DNA Test (IDEXX, Westbrook, USA) was used following the manufacturer's instructions. For confirmatory purposes, the OIE-listed protocol by King et al. (2003) was used with slight modifications. At the German national reference laboratory (NRL at the FLI), qPCRs were performed according to the protocols published by King et al. (2003) and Tignon et al. (2011). Both assays were used with adapted internal control systems. In addition, a commercial qPCR kit was employed (virotype ASFV, Indical Bioscience, Leipzig, Germany) according to the manufacturer's instructions. To isolate the causative ASFV in serum and tissue samples, a haemadsorption test (HAT) was performed using PBMC-derived macrophages according to slightly modified standard procedures (Carrascosa, Bustos, \& de Leon, 2011).

\section{Next-generation sequencing}

For whole-genome sequencing, DNA was extracted from $200 \mu \mathrm{l}$ of bone-marrow homogenate using the NucleoMagVet kit (Macherey-Nagel, Düren, Germany) according to the manufacturers' protocol. For rapid generation of sequence information, DNA from the same sample was sequenced on the Illumina MiSeq platform (San Diego, USA) as described elsewhere (Wylezich, Papa, Beer, \& Hoper, 2018).

The resulting read data was mapped against a custom database including all ASFV sequences available from International Nucleotide Sequence Database Collaboration (INSDC) databases as of 15th September 2020 
using Bowtie2 v.2.3.5.1 (Langmead \& Salzberg, 2012) with the highest sensitivity settings followed by de novo assembly of the mapped reads using SPAdes v.3.13 (Antipov, Korobeynikov, McLean, \& Pevzner, 2016) with default parameters. The resulting whole-genome sequence was aligned with all other available ASFV whole-genome sequences from INSDC-databases (as of 21st September 2020) using MAFFT v7.388 (Katoh \& Standley, 2013) in Geneious Prime v.2019.2.3 (Biomatters, Auckland, New Zealand), annotated on the basis of ASFV Georgia 2007/1 (FR682468.2) using Geneious, and a phylogenetic tree was constructed with IQTREE v 1.6.5 (Hoang, Chernomor, von Haeseler, Minh, \& Vinh, 2018; Kalyaanamoorthy, Minh, Wong, von Haeseler, \& Jermiin, 2017; Nguyen, Schmidt, von Haeseler, \& Minh, 2015). Whole genome sequences from Poland were kindly provided by N. Mazur and G. Woźniakowski ahead of publication in INSDC databases and compared to the ASFV Germany 2020/1 whole-genome sequence using MAFFT v.7.388 with default parameters in Geneious prime.

\section{Results and discussion}

\section{Case description and epidemiological situation}

The carcass of an adult female was found in a ditch between two harvested maize fields at a dry location exposed to direct sunlight, about $200 \mathrm{~m}$ off a country road in a community of the Spree-Neiße district, Brandenburg, Germany ca. $6 \mathrm{~km}$ from the border with Poland (Figure 1) by a person walking the dog. Foreleg bones of the largely decomposed carcass were submitted by the responsible hunter for ASFV testing and the carcass was buried on site on 7th September 2020. At the time of detection, the hunter noticed large numbers of maggots on and around the carcass. The mean temperature was $15^{\circ} \mathrm{C}(1 \mathrm{st}-7$ th September 2020 ) or $19^{\circ} \mathrm{C}$ (6th August - 7th September 2020), respectively. From 1st August - 9th September 2020, the average rainfall was $6 \mathrm{~mm}$. The carcass was found in an advanced stage of decomposition and the minimum PMI was estimated at two weeks. At that time, the adjacent region in Poland was classified as a part I-region according to the implementing decision EU 2014/709, i.e. with a certain risk regarding ASF due to proximity of the infection in the feral population (Figure 1).

Since the occurrence of ASF in wild boar in Western Poland, the risk of introduction of ASF into Germany by migrating infected wild boar had substantially increased. Preventive measures such as building a mobile fence along the Polish border and increased surveillance in wild boar and domestic pigs were introduced. The direct distance from the first detected case in Brandenburg to the nearest ASF case in Poland, which was confirmed within the preceding four weeks (13th August to 9th September 2020), was $33.9 \mathrm{~km}$. The ASF case in Poland nearest to Germany was detected at a distance of $10.4 \mathrm{~km}$ from the German border, but south of the now affected area. Due to lack of information on the surveillance intensity between the national border and the ASF focus in Western Poland, direct evidence for a westward expansion of the infected area in Western Poland is missing. Yet, it seems likely that the disease has been introduced by migrating wild boar. (A new case, confirmed on 30th September 2020, located approx. $60 \mathrm{~km}$ north of the focus of the first introduction into Germany, was also detected less than $2 \mathrm{~km}$ away from the border with Poland). However, it cannot be excluded that human activity (e.g. unsafe disposal of contaminated material) may have caused the initial infection. ASFV remains infectious for a long time in pig products, especially if blood is contained (Fischer, Hühr, Blome, Conraths, \& Probst, 2020; Kolbasov, Tsybanov, Malogolovkin, Gazaev, \& Mikolaxchuk, 2011; Mebus et al., 1997).

Wild boar and domestic pigs have been intensively monitored for ASF in Germany in recent years. Especially in areas close to the German-Polish-border, the efforts were intensified after the emergence of the disease in Western Poland. Figure 2 shows the results of surveillance within the affected region close to the GermanPolish border for the period from 1st November 2019 to 9th September 2020. A total of 7.125 samples of wild boar (6.081 apparently healthy shot wild boar, 312 wild boar found dead, 74 animals shot sick and 658 animals killed in road traffic accidents) tested negative for ASF. Most wild boar are examined during winter, when hunting is at its maximum. Nevertheless, in the four months before the detection of the first case of ASF in Germany, 50 wild boar found dead, 12 animals shot sick and 165 animals killed in road traffic accidents also tested negative for ASFV. 
During the following days of intensified carcass search, four more carcasses and a hunted wild boar with clinical signs were found $6 \mathrm{~km}$ away from the first site. These carcasses were fresh with an estimated minimum PMI of only a few days. Until 24th September 2020, a total of 32 cases of ASF were confirmed, of which nine were found close to the first site and 23 in a small area further north (Figure 3). In both locations, fresh and old carcasses of young and old wild boar were found (14 piglets, 6 subadults, 6 adult animals; the age of 6 animals could not be assessed) (Table 1). At the place, where most carcasses were found, the carcasses with the longest minimum PMI of 80 days were detected (Table 1).

PMI estimates were based on the macroscopically visible stage of decay, the presence of insects and the microclimatic conditions at the sites. However, when decomposition had reached an advanced stage and only single skeletal remains were found, dating the PMI became difficult, in particular when carcasses had obviously been used by large vertebrate scavengers (red foxes and wolves are present in the area).

Based on the available data, the virus was probably introduced into Germany in early July 2020 or even earlier. Since most of the detected ASFV-infected wild boar died in September 2020 (Table 1), the situation is still evolving.

From all these animals, dry blood swabs or bones (carcasses) or serum (shot wild boar) were sent for laboratory diagnosis to the LLBB and for confirmation to the NRL at the FLI.

\section{Routine diagnosis and confirmation}

The standard procedure in Germany for the diagnosis of ASF includes an initial testing in an accredited state laboratory in the affected federal state. These laboratories regularly participate in an inter-laboratory comparison test performed by the NRL (see also tasks of the NRL according to Council Directive 2002/60/EC). Samples with a positive or inconclusive result are sent to the NRL for confirmation. Only the diagnosis of the NRL confirms an outbreak or case. Suitable diagnostic tests are listed in the official method collection published by the FLI, taking into account the EU Diagnostic Manual (Commission Decision 2003/422/EC).

Despite the advanced state of decomposition of the first carcass and the resulting low sample quality, the LLBB detected moderate amounts of genome sequences of ASF virus. At the FLI, these results were confirmed with very similar cq-values, despite the use of different cyclers and conditions. By 24th September 2020, 32 cases were detected at the LLBB and confirmed by FLI. Sample matrices were 19 bone marrow specimens from carcasses of varying stages of decomposition, 12 blood swab suspensions, and 1 blood clot suspension and the corresponding serum. Cycle threshold values ranged from 18 to 36 in the OIE-recommended PCR by King et al. (2003) and were comparable between the regional and national laboratory. As expected, PCRs that amplified short genome fragments performed better on poor quality samples. A combination of different test systems, also for internal control, is therefore advisable and has proven to be effective in the present case. Details are shown in Table 1. Blood swab suspensions, which had been included into the official method collection following extensive validation studies under experimental and limited field conditions at the NRL (Carlson et al., 2018; Petrov et al., 2014), yielded reliable results also in this outbreak situation. The hemadsorbing virus causing this outbreak was isolated from the serum sample mentioned above.

Following the confirmation of the first case, the local veterinary authority had the remains of the carcass exhumed for further pathological examination at the LLBB. All samples taken from the carcass, even muscle and fatty tissues were positive in qPCR (see Supplementary Table 1). This fact underlines that any sample should be send if the recommended samples are not available. In this case, communication should be established with the receiving laboratory.

Positive samples were also obtained when diluting the samples 1:5. The latter would mimic the pooling options currently provided in the official method collection.

Next-generation sequencing and phylogenetic analyses

Sequencing resulted in 18.865.783 single-end and 46.020 .040 paired-end 300 bp reads from which 1.228 .953 reads $(1.89 \%)$ mapped to the ASFV reference database and were assembled with a coverage of 2082 . The 
ASFV Germany 2020/1 whole-genome sequence encompasses 190,592 bp with a G/C content of 38.4\%. Phylogenetically it groups with sequences from ASFV genotype II including all sequences from Eastern Europe, Asia and Belgium (Figure 4). The ASFV Germany 2020/1 sequence shows 99.9\% nucleotide sequence identity to the whole-genome sequence of ASFV_Pol17_55892_ C754 (MT847620), which originated from an outbreak south of Warsaw (Piaseczno province, Mazowieckie voivodeship) in 2017 (Mazur-Panasiuk et al., 2020). Furthermore, some characteristic markers e.g. a 14 bp insertion in the O174L gene, a single nucleotide variation in the K145R gene, the MGF 505-5R gene and the K205R gene as well as a one tandem repeat integration in the intergenic region between the genes I73R and I329L described in Poland (Mazur-Panasiuk et al., 2020; Mazur-Panasiuk, Wozniakowski, \& Niemczuk, 2019) were also present in ASFV Germany 2020/1. These are in accordance with characteristics found in ASFV sequences from Southern Warsaw and Western Poland (Mazur-Panasiuk et al., 2020; Mazur-Panasiuk et al., 2019) and clearly distinguish ASFV Germany 2020/1 from all other ASFV GTII whole-genome sequences including those from the Czech Republic (LR722600.1), Belgium (LR536725.1), Moldova (LR722599.1) and Georgia (FR682468.2).

\section{Acknowledgements}

We thank all the hunters, veterinarians and individuals, who kept their vigilance and reported dead found wild boar to the authorities. We thank Patrick Zitzow, Ulrike Kleinert, Anja Schulz, Patrick Wysocki, Daike Lehnau and Stephan Eichenberg for their excellent technical assistance and Gernot Schmoock and Lisa Sprague for assisting with MiSeq sequencing.

\section{Conflict of interest statement}

The authors declare no conflict of interest.

\section{Ethical approval}

This work does not include any animal experiments. Only dead wild boar were sampled. Sampling of these animals is prescribed according to the German Swine Fever Ordinance (Schweinepest-Verordnung) in accordance with the German Animal Health Law (Tiergesundheitsgesetz). Ethical approval for sampling the carcasses was therefore not required.

\section{Data Availability Statement}

The data that support the findings of this study are available from the corresponding author upon reasonable request. The sequence data generated in this study is available from INSDC databases under study accession number PRJEB40536.

\section{References}

Antipov, D., Korobeynikov, A., McLean, J. S., \& Pevzner, P. A. (2016). hybridSPAdes: an algorithm for hybrid assembly of short and long reads.Bioinformatics, 32 (7), 1009-1015. doi:10.1093/bioinformatics/btv688

Blome, S., Franzke, K., \& Beer, M. (2020). African swine fever - A review of current knowledge. Virus Res, 287 , 198099. doi:doi:10.1016/j.virusres.2020.198099

Carlson, J., Zani, L., Schwaiger, T., Nurmoja, I., Viltrop, A., Vilem, A., . . Blome, S. (2018). Simplifying sampling for African swine fever surveillance: Assessment of antibody and pathogen detection from blood swabs. Transbound Emerg Dis, 65 (1), e165-e172. doi:10.1111/tbed.12706

Carrascosa, A. L., Bustos, M. J., \& de Leon, P. (2011). Methods for growing and titrating African swine fever virus: field and laboratory samples. Curr Protoc Cell Biol, Chapter 26 , Unit 2614. doi:10.1002/0471143030.cb2614s53

Chenais, E., Depner, K., Guberti, V., Dietze, K., Viltrop, A., \& Stahl, K. (2019). Epidemiological considerations on African swine fever in Europe 2014-2018. Porcine Health Manag, 5 , 6. doi:10.1186/s40813-018-0109-2

Fischer, M., Hühr, J., Blome, S., Conraths, F. J., \& Probst, C. (2020). Stability of African swine fever virus in carcasses of domestic pigs and wild boar experimentally infected with the ASFV 'Estonia 2014' 
isolate. Viruses, 2020 .

Hoang, D. T., Chernomor, O., von Haeseler, A., Minh, B. Q., \& Vinh, L. S. (2018). UFBoot2: Improving the Ultrafast Bootstrap Approximation. Mol Biol Evol, 35 (2), 518-522. doi:10.1093/molbev/msx281

Kalyaanamoorthy, S., Minh, B. Q., Wong, T. K. F., von Haeseler, A., \& Jermiin, L. S. (2017). ModelFinder: fast model selection for accurate phylogenetic estimates. Nat Methods, 14 (6), 587-589. doi:10.1038/nmeth.4285

Katoh, K., \& Standley, D. M. (2013). MAFFT multiple sequence alignment software version 7: improvements in performance and usability. Mol Biol Evol, 30 (4), 772-780. doi:10.1093/molbev/mst010

King, D. P., Reid, S. M., Hutchings, G. H., Grierson, S. S., Wilkinson, P. J., Dixon, L. K., . . Drew, T. W. (2003). Development of a TaqMan PCR assay with internal amplification control for the detection of African swine fever virus. J Virol Methods, 107 (1), 53-61. doi:10.1016/s0166-0934(02)00189-1

Kolbasov, D., Tsybanov, S., Malogolovkin, A., Gazaev, I., \& Mikolaxchuk, S. (2011). Identification of ASF virus in pork products. Veterinaria, $10,54-56$.

Kroschewski, K., Kramer, M., Micklich, A., Staubach, C., Carmanns, R., \& Conraths, F. J. (2006). Animal disease outbreak control: the use of crisis management tools. Rev Sci Tech, 2006 Apr 25 (1), 211-221. doi:doi: 10.20506/rst.25.1.1657.PMID: 16796050

Langmead, B., \& Salzberg, S. L. (2012). Fast gapped-read alignment with Bowtie 2. Nat Methods, 9 (4), 357-359. doi:10.1038/nmeth.1923

Linden, A., Licoppe, A., Volpe, R., Paternostre, J., Lesenfants, C., Cassart, D., . . Cay, A. B. (2019). Summer 2018: African swine fever virus hits north-western Europe. Transbound Emerg Dis, 66 (1), 54-55. doi:10.1111/tbed.13047

Mazur-Panasiuk, N., Walczak, M., Juszkiewicz, M., \& Wozniakowski, G. (2020). The Spillover of African Swine Fever in Western Poland Revealed Its Estimated Origin on the Basis of O174L, K145R, MGF 505-5R and IGR I73R/I329L Genomic Sequences. Viruses, 12 (10). doi:10.3390/v12101094

Mazur-Panasiuk, N., Wozniakowski, G., \& Niemczuk, K. (2019). The first complete genomic sequences of African swine fever virus isolated in Poland. Sci Rep, 9 (1), 4556. doi:10.1038/s41598-018-36823-0

Mebus, C. A., Arias, M., Pineda, J. M., Tapiador, J., House, C., \& Sanchez-Vizcaino, F. (1997). Survival of several porcine viruses in different Spanish dry-cured meat products. Food Chem, 59 (4), 555-559.

Nguyen, L. T., Schmidt, H. A., von Haeseler, A., \& Minh, B. Q. (2015). IQ-TREE: a fast and effective stochastic algorithm for estimating maximum-likelihood phylogenies. Mol Biol Evol, 32 (1), 268-274. doi:10.1093/molbev/msu300

Pebesma, E. J., \& Bivand, R. S. (2005). Classes and methods for spatial data in R. R News, 5 (2), 9-13.

Petrov, A., Schotte, U., Pietschmann, J., Drager, C., Beer, M., Anheyer-Behmenburg, H., . . Blome, S. (2014). Alternative sampling strategies for passive classical and African swine fever surveillance in wild boar. Vet Microbiol, 173 (3-4), 360-365. doi:10.1016/j.vetmic.2014.07.030

Probst, C., Gethmann, J., Amendt, J., Lutz, L., Teifke, J. P., \& Conraths, F. J. (2020). Estimating the Postmortem Interval of Wild Boar Carcasses. Vet Sci, 7 (1). doi:10.3390/vetsci7010006

Probst, C., Gethmann, J., Hohmann, U., Knoll, B., Amendt, J., Teifke, J. P., \& Conraths, F. J. (2020). Zersetzungsstadien bei Wildschweinkadavern - und wie die Liegezeit geschätzt werden kann.Amtstierärztlicher Dienst und Lebensmittelkontrolle, 2 .

Tignon, M., Gallardo, C., Iscaro, C., Hutet, E., Van der Stede, Y., Kolbasov, D., . . Koenen, F. (2011). Development and inter-laboratory validation study of an improved new real-time PCR assay with internal 
control for detection and laboratory diagnosis of African swine fever virus. Journal of virological methods, 178 (1-2), 161-170. doi:10.1016/j.jviromet.2011.09.007

Wylezich, C., Papa, A., Beer, M., \& Hoper, D. (2018). A Versatile Sample Processing Workflow for Metagenomic Pathogen Detection. Sci Rep, 8 (1), 13108. doi:10.1038/s41598-018-31496-1

Table 1: Wild boar samples examined for ASF in Brandenburg, Germany (from 10th September to 24th September 2020)

\begin{tabular}{|c|c|c|c|c|c|c|c|c|c|c|}
\hline ID & County & Matrix & $\begin{array}{l}\text { Age } \\
\text { class }\end{array}$ & Gender & $\begin{array}{l}\text { Sample } \\
\text { origin } \\
+\end{array}$ & $\begin{array}{l}\text { Estima } \\
\text { mini- } \\
\text { mum } \\
\text { PMI } \\
\text { (days) } \\
++\end{array}$ & $\begin{array}{l}\text { Estimated } \\
\text { latest } \\
\text { date of } \\
\text { death } \S\end{array}$ & $\begin{array}{l}\text { LLBB } \\
\text { IDEXX } \\
\text { ASFV }\end{array}$ & $\begin{array}{l}\text { NRL } \\
\text { ASF } \\
\text { King } \\
\text { PCR }\end{array}$ & $\begin{array}{l}\text { NRL } \\
\text { ASF } \\
\text { vi- } \\
\text { rotype } \\
\text { ASFV }\end{array}$ \\
\hline 1 & $\begin{array}{l}\text { LK } \\
\text { Spree- } \\
\text { Neiße }\end{array}$ & $\begin{array}{l}\text { Bone } \\
\text { marrow }\end{array}$ & Adult & Female & $?$ & 14 & 24.08 .2020 & 24 & 23 & 21 \\
\hline 2 & $\begin{array}{l}\text { LK } \\
\text { Oder- } \\
\text { Spree }\end{array}$ & $\begin{array}{l}\text { Swab } \\
\text { suspension }\end{array}$ & Subadult & Female & $?$ & 0 & 11.09 .2020 & 30 & 29 & 27 \\
\hline 3 & $\begin{array}{l}\text { LK } \\
\text { Oder- } \\
\text { Spree }\end{array}$ & $\begin{array}{l}\text { Blood } \\
\text { clot } \\
\text { suspension }\end{array}$ & Piglet & n.d. & $?$ & 1 & 11.09 .2020 & 20 & 21 & 21 \\
\hline 4 & $\begin{array}{l}\text { LK } \\
\text { Oder- } \\
\text { Spree }\end{array}$ & $\begin{array}{l}\text { Swab } \\
\text { suspension }\end{array}$ & Subadult & Female & $?$ & $\begin{array}{l}\text { Few } \\
\text { days }\end{array}$ & 10.09 .2020 & 30 & 25 & 29 \\
\hline 5 & $\begin{array}{l}\text { LK } \\
\text { Oder- } \\
\text { Spree }\end{array}$ & $\begin{array}{l}\text { Swab } \\
\text { suspension }\end{array}$ & Adult & Female & $?$ & $\begin{array}{l}\text { Few } \\
\text { days }\end{array}$ & 11.09 .2020 & 25 & 25 & 24 \\
\hline 6 & $\begin{array}{l}\text { LK } \\
\text { Oder- } \\
\text { Spree }\end{array}$ & $\begin{array}{l}\text { Swab } \\
\text { suspension }\end{array}$ & Piglet & n.d. & $?$ & $\begin{array}{l}\text { Few } \\
\text { days }\end{array}$ & 08.09.2020 & 25 & 25 & 24 \\
\hline 7 & $\begin{array}{l}\text { LK } \\
\text { Oder- } \\
\text { Spree }\end{array}$ & $\begin{array}{l}\text { Swab } \\
\text { suspension }\end{array}$ & Subadult & Female & $?$ & 3 & 10.09 .2020 & 24 & 26 & 23 \\
\hline 8 & $\begin{array}{l}\text { LK } \\
\text { Oder- } \\
\text { Spree }\end{array}$ & $\begin{array}{l}\text { Swab } \\
\text { suspension }\end{array}$ & Piglet & n.d. & $?$ & 5 & 10.09 .2020 & 28 & 28 & 25 \\
\hline 9 & $\begin{array}{l}\text { LK } \\
\text { Oder- } \\
\text { Spree }\end{array}$ & $\begin{array}{l}\text { Swab } \\
\text { suspension }\end{array}$ & Piglet & n.d. & $?$ & 0 & 15.09 .2020 & 26 & 25 & 24 \\
\hline 10 & $\begin{array}{l}\text { LK } \\
\text { Spree- } \\
\text { Neiße }\end{array}$ & $\begin{array}{l}\text { Bone } \\
\text { marrow }\end{array}$ & Subadult & Male & $?$ & n.d. & n.d. & 27 & 30 & 27 \\
\hline 11 & $\begin{array}{l}\text { LK } \\
\text { Spree- } \\
\text { Neiße }\end{array}$ & $\begin{array}{l}\text { Bone } \\
\text { marrow }\end{array}$ & Piglet & n.d. & $?$ & 30 & 17.08.2020 & 33 & 35 & 29 \\
\hline 12 & $\begin{array}{l}\text { LK } \\
\text { Spree- } \\
\text { Neiße }\end{array}$ & $\begin{array}{l}\text { Bone } \\
\text { marrow }\end{array}$ & Subadult & Male & $?$ & n.d. & n.d. & 29 & no $c q$ & 33 \\
\hline
\end{tabular}




\begin{tabular}{|c|c|c|c|c|c|c|c|c|c|c|}
\hline ID & County & Matrix & $\begin{array}{l}\text { Age } \\
\text { class }\end{array}$ & Gender & $\begin{array}{l}\text { Sample } \\
\text { origin } \\
+\end{array}$ & $\begin{array}{l}\text { Estima } \\
\text { mini- } \\
\text { mum } \\
\text { PMI } \\
\text { (days) } \\
++\end{array}$ & $\begin{array}{l}\text { Estimatec } \\
\text { latest } \\
\text { date of } \\
\text { death } \S\end{array}$ & $\begin{array}{l}\text { d } \\
\text { LLBB } \\
\text { IDEXX } \\
\text { ASFV }\end{array}$ & $\begin{array}{l}\text { NRL } \\
\text { ASF } \\
\text { King } \\
\text { PCR }\end{array}$ & $\begin{array}{l}\text { NRL } \\
\text { ASF } \\
\text { vi- } \\
\text { rotype } \\
\text { ASFV }\end{array}$ \\
\hline 13 & $\begin{array}{l}\text { LK } \\
\text { Spree- } \\
\text { Neiße }\end{array}$ & $\begin{array}{l}\text { Bone } \\
\text { marrow }\end{array}$ & Piglet & n.d. & $?$ & 7 & 09.09.2020 & 31 & 36 & 30 \\
\hline 14 & $\begin{array}{l}\text { LK } \\
\text { Oder- } \\
\text { Spree }\end{array}$ & $\begin{array}{l}\text { Swab } \\
\text { suspension }\end{array}$ & Subadult & Female & $?$ & 1 & 16.09 .2020 & 23 & 21 & n.d. \\
\hline 15 & $\begin{array}{l}\text { LK } \\
\text { Oder- } \\
\text { Spree }\end{array}$ & $\begin{array}{l}\text { Bone } \\
\text { marrow }\end{array}$ & Adult & Female & $?$ & 60 & 20.07 .2020 & 30 & 33 & 31 \\
\hline 16 & $\begin{array}{l}\text { LK } \\
\text { Oder- } \\
\text { Spree }\end{array}$ & $\begin{array}{l}\text { Swab } \\
\text { suspension }\end{array}$ & Piglet & n.d. & $?$ & 4 & 14.09 .2020 & 26 & 25 & 23 \\
\hline 17 & $\begin{array}{l}\text { LK } \\
\text { Spree- } \\
\text { Neiße }\end{array}$ & $\begin{array}{l}\text { Bone } \\
\text { marrow }\end{array}$ & Piglet & n.d. & $?$ & n.d. & n.d. & 37 & 35 & no $c q$ \\
\hline 18 & $\begin{array}{l}\text { LK } \\
\text { Spree- } \\
\text { Neiße }\end{array}$ & $\begin{array}{l}\text { Bone } \\
\text { marrow }\end{array}$ & Piglet & n.d. & $?$ & n.d. & n.d. & 19 & 20 & 17 \\
\hline 19 & $\begin{array}{l}\text { LK } \\
\text { Spree- } \\
\text { Neiße }\end{array}$ & $\begin{array}{l}\text { Bone } \\
\text { marrow }\end{array}$ & Piglet & n.d. & $?$ & 2 & 17.09 .2020 & 21 & 18 & 17 \\
\hline 20 & $\begin{array}{l}\text { LK } \\
\text { Spree- } \\
\text { Neiße }\end{array}$ & $\begin{array}{l}\text { Bone } \\
\text { marrow }\end{array}$ & Adult & Female & $?$ & 14 & 05.09 .2020 & 23 & 23 & 22 \\
\hline 21 & $\begin{array}{l}\text { LK } \\
\text { Oder- } \\
\text { Spree }\end{array}$ & $\begin{array}{l}\text { Swab } \\
\text { suspension }\end{array}$ & Piglet & n.d. & $?$ & 7 & 12.09.2020 & 22 & 21 & 18 \\
\hline 22 & $\begin{array}{l}\text { LK } \\
\text { Oder- } \\
\text { Spree }\end{array}$ & $\begin{array}{l}\text { Swab } \\
\text { suspension }\end{array}$ & Piglet & n.d. & $?$ & 1 & 18.09 .2020 & 26 & 25 & 24 \\
\hline 23 & $\begin{array}{l}\text { LK } \\
\text { Oder- } \\
\text { Spree }\end{array}$ & $\begin{array}{l}\text { Bone } \\
\text { marrow }\end{array}$ & n.d. & Female & $?$ & 80 & 01.07 .2020 & 35 & 36 & 29 \\
\hline 24 & $\begin{array}{l}\text { LK } \\
\text { Oder- } \\
\text { Spree }\end{array}$ & $\begin{array}{l}\text { Bone } \\
\text { marrow }\end{array}$ & $\begin{array}{l}\text { n.d., } \\
\text { only } \\
\text { bones } \\
\text { left }\end{array}$ & $\begin{array}{l}\text { Female } \\
(?)\end{array}$ & $?$ & 80 & 01.07 .2020 & 32 & 31 & 29 \\
\hline 25 & $\begin{array}{l}\text { LK } \\
\text { Oder- } \\
\text { Spree }\end{array}$ & $\begin{array}{l}\text { Bone } \\
\text { marrow }\end{array}$ & Piglet & n.d. & $?$ & 7 & 12.09 .2020 & 20 & 19 & 18 \\
\hline 26 & $\begin{array}{l}\text { LK } \\
\text { Oder- } \\
\text { Spree }\end{array}$ & $\begin{array}{l}\text { Bone } \\
\text { marrow }\end{array}$ & $\begin{array}{l}\text { n.d., } \\
\text { only } \\
\text { bones } \\
\text { left }\end{array}$ & $\begin{array}{l}\text { Male } \\
(?)\end{array}$ & $?$ & 10 & 09.09.2020 & 26 & 27 & 23 \\
\hline
\end{tabular}




\begin{tabular}{|c|c|c|c|c|c|c|c|c|c|c|}
\hline ID & County & Matrix & $\begin{array}{l}\text { Age } \\
\text { class }\end{array}$ & Gender & $\begin{array}{l}\text { Sample } \\
\text { origin } \\
+\end{array}$ & $\begin{array}{l}\text { Estima } \\
\text { mini- } \\
\text { mum } \\
\text { PMI } \\
\text { (days) } \\
++\end{array}$ & $\begin{array}{l}\text { Estimatec } \\
\text { latest } \\
\text { date of } \\
\text { death } \S\end{array}$ & $\begin{array}{l}\text { d } \\
\text { LLBB } \\
\text { IDEXX } \\
\text { ASFV }\end{array}$ & $\begin{array}{l}\text { NRL } \\
\text { ASF } \\
\text { King } \\
\text { PCR }\end{array}$ & $\begin{array}{l}\text { NRL } \\
\text { ASF } \\
\text { vi- } \\
\text { rotype } \\
\text { ASFV }\end{array}$ \\
\hline 27 & $\begin{array}{l}\text { LK } \\
\text { Oder- } \\
\text { Spree }\end{array}$ & $\begin{array}{l}\text { Bone } \\
\text { marrow }\end{array}$ & $\begin{array}{lr}\text { n.d., } & \text { r } \\
\text { decomposed }\end{array}$ & n.d. & $?$ & 10 & 10.09 .2020 & 28 & 27 & 26 \\
\hline 28 & $\begin{array}{l}\text { LK } \\
\text { Oder- } \\
\text { Spree }\end{array}$ & $\begin{array}{l}\text { Bone } \\
\text { marrow }\end{array}$ & Adult & Female & $?$ & 6 & 13.09 .2020 & 26 & 25 & 24 \\
\hline 29 & $\begin{array}{l}\text { LK } \\
\text { Oder- } \\
\text { Spree }\end{array}$ & $\begin{array}{l}\text { Bone } \\
\text { marrow }\end{array}$ & $\begin{array}{lr}\text { n.d., } & \mathrm{r} \\
\text { decomposed }\end{array}$ & $\begin{array}{l}\text { n.d. } \\
\text { d }\end{array}$ & $?$ & 10 & 09.09.2020 & 25 & 22 & 21 \\
\hline 30 & $\begin{array}{l}\text { LK } \\
\text { Oder- } \\
\text { Spree }\end{array}$ & $\begin{array}{l}\text { Bone } \\
\text { marrow }\end{array}$ & n.d. & Female & $?$ & 30 & 22.08 .2020 & 20 & 24 & 21 \\
\hline 31 & $\begin{array}{l}\text { LK } \\
\text { Oder- } \\
\text { Spree }\end{array}$ & $\begin{array}{l}\text { Bone } \\
\text { marrow }\end{array}$ & Piglet & n.d. & $?$ & 14 & 07.09.2020 & 19 & 19 & 18 \\
\hline 32 & $\begin{array}{l}\text { LK } \\
\text { Oder- } \\
\text { Spree }\end{array}$ & $\begin{array}{l}\text { Swab } \\
\text { suspension }\end{array}$ & Adult & Male & $?$ & 2 & 19.09 .2020 & 25 & 27 & 23 \\
\hline
\end{tabular}

n.d.: not determined

+ Sample origin: ?: carcass; ?: shot sick

++ Estimated minimum Postmortem Interval (PMI)

$\S$ Estimated latest date of death: calculated as: finding date minus minimum postmortem-interval

\section{Figure legends}

Figure 1: Location of the first wild boar found dead in Germany in relation to the ASF restriction zones in Western Poland (as of 10th September, 2020). Red line: German-Polish border, black lines: borders between federal states in Germany and Voivodeships in Poland.

Figure 2 Surveillance effort since 1st November 2019 until 9th September 2020 in the federal state Brandenburg. (Blue dots: passive surveillance: shot sick, found dead, involved in road traffic accidents; yellow dots: active surveillance: shot apparently healthy.)

Figure 3: Locations of ASF cases in wild boar in Germany (as of 24th September 2020). Yellow star: first detected case with estimated death date in August 2020; red dots: cases with estimated death date in July 2020; yellow dots: cases with estimated death date in August 2020; green dots: cases with estimated death date in September 2020; black dots: cases, where the death date could not be estimated.

Figure 4: Phylogenetic reconstruction of ASFV whole genome sequences. The phylogenetic tree was constructed from MAFFT v7.388 aligned whole-genome sequences kindly provided by N. Mazur-Panasiuk and G. Woźniakowski and downloaded from INSDC-databases on 21st September 2020 using IQTREE v 1.6.5 with automatically selected models $\mathrm{GTR}+\mathrm{F}+\mathrm{R} 3$ (general time reversible model with unequal rates and unequal base frequency + empirical base frequencies + FreeRate model with 3 categories). Statistical support of 10,000 ultrafast bootstraps using the ultrafast bootstrap approximation (UFBoot) (percentage values) 
is indicated at the nodes. Taxon names include, where available, ASFV designation and INSDC accession number. The scale bar represents number of substitutions per site. The ASFV P72 genotype II sequences (yellow) and the ASFV Germany 2020/1 sequence (red) are highlighted.
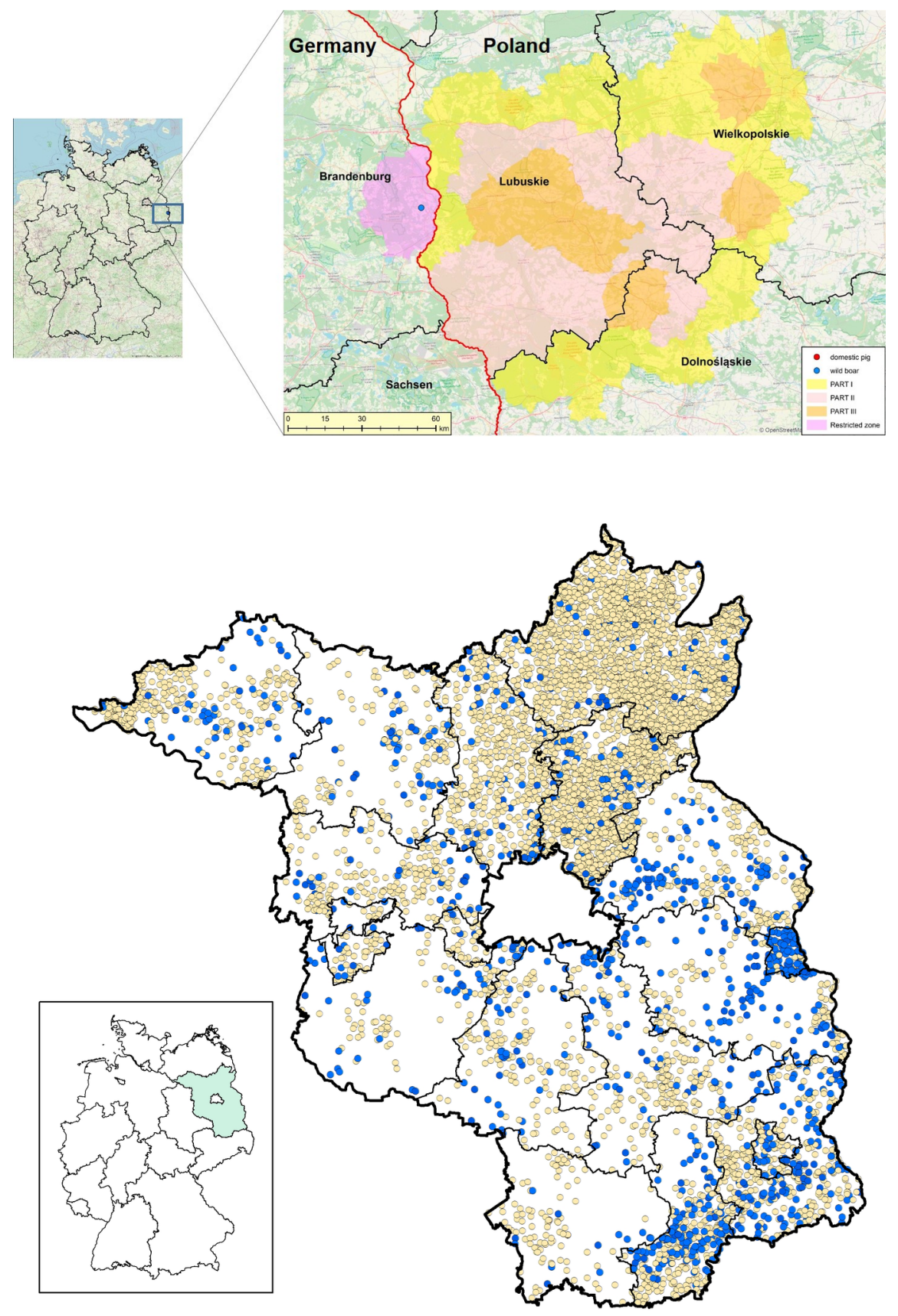


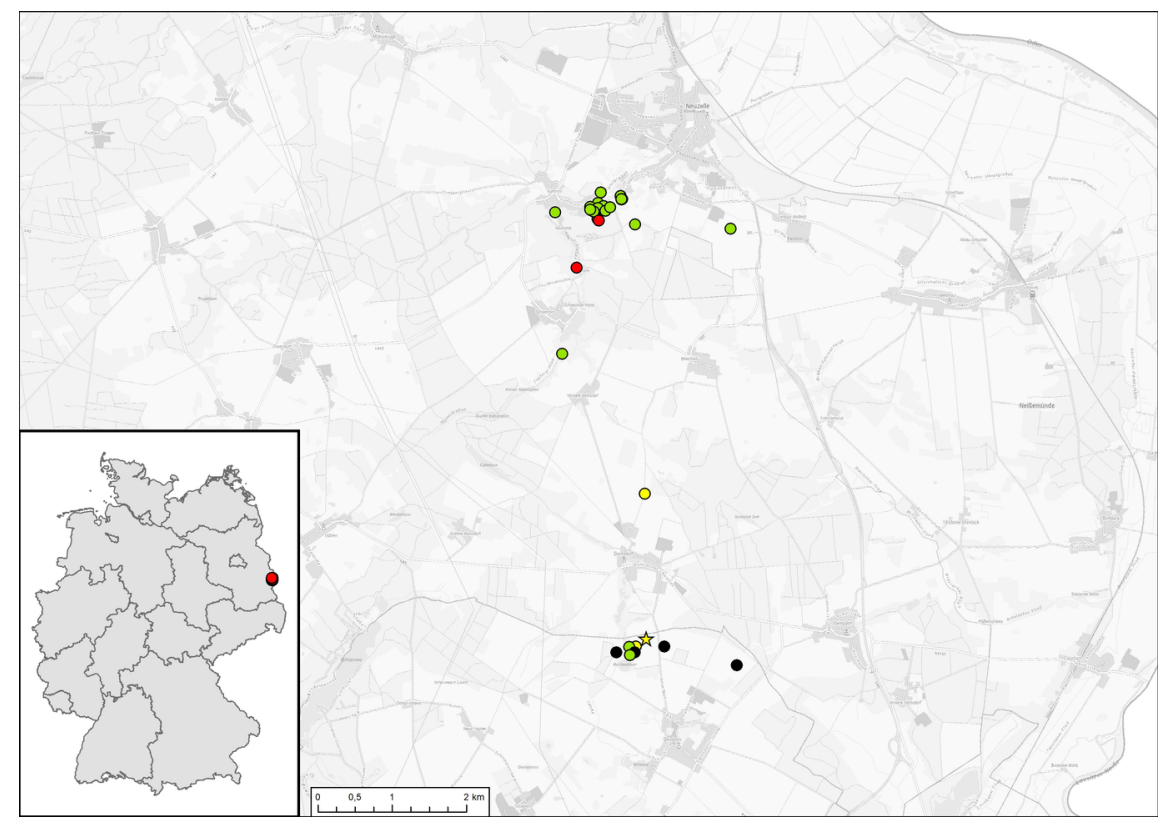




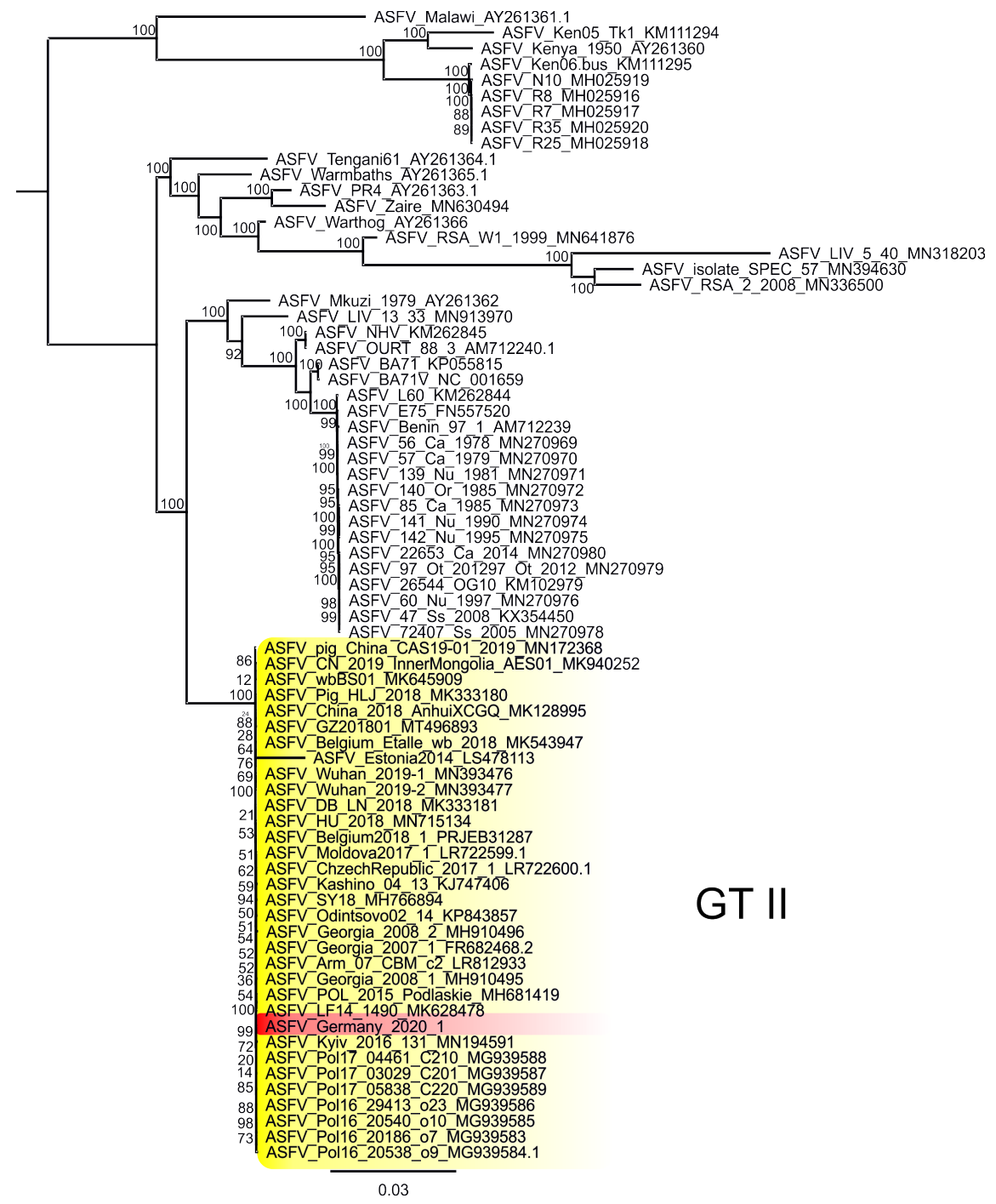

